\title{
Influence of Aerobic and Phototrophic Growth Conditions on the Distribution of Glucose and Fructose Carbon into the Entner-Doudoroff and Embden-Meyerhof Pathways in Rhodopseudomonas sphaeroides
}

\author{
By R. CONRAD AND H. G. SCHLEGEL \\ Institut für Mikrobiologie der Gesellschaft für Strahlen- und Umweltforschung $m b H$ \\ und der Universität, Grisebachstrasse 8, D-3400 Göttingen, \\ Federal Republic of Germany
}

(Received II February 1977)

\begin{abstract}
In aerobically and phototrophically growing cells of Rhodopseudomonas sphaeroides, glucose and fructose catabolism were studied by means of enzyme analysis, radiorespirometry and incorporation of specifically-labelled glucose and fructose into spheroidene fractions, into alanine and into valine. Bacteria grown on glucose or fructose possessed all the enzymes necessary for sugar catabolism via the Entner-Doudoroff pathway. Bacteria grown on fructose also contained an inducible I-phosphofructokinase, indicating that fructose was degraded via fructose I-phosphate. Fructose was catabolized via both the Embden-Meyerhof and Entner-Doudoroff pathways. The contribution of each pathway to fructose breakdown was influenced by the growth conditions: under phototrophic conditions fructose was catabolized predominantly via the Embden-Meyerhof pathway; under aerobic conditions it was catabolized mainly via the Entner-Doudoroff pathway. This change in the major fructose catabolic pathway was paralleled by fructose-I, 6-bisphosphate aldolase activity: the activity was high in phototrophically growing cells and low in aerobically growing cells. Glucose, on the other hand, was catabolized via the Entner-Doudoroff pathway under both phototrophic and aerobic conditions.
\end{abstract}

\section{INTRODUCTION}

Like Rhodopseudomonas capsulata, Rhodopseudomonas sphaeroides is able to grow both aerobically and phototrophically on glucose and fructose. Rhodopseudomonas capsulata catabolizes glucose via the Entner-Doudoroff pathway (EDP) and fructose via the EmbdenMeyerhof pathway (EMP) (Conrad \& Schlegel, I977). Both $R$. capsulata and $R$. sphaeroides contain a phosphoenolpyruvate (PEP)-fructose phosphotransferase system and I-phosphofructokinase which are induced by fructose (Saier, Feucht \& Roseman, I97I ; Conrad \& Schlegel, 1974, 1977). As in $R$. capsulata, all the enzymes of the EDP are present in glucoseand fructose-grown $R$. sphaeroides (Szymona \& Doudoroff, 1960) and are induced by these hexoses (Ohmann, Rindt \& Borriss, 1969). Therefore, it seemed likely that the glucose and fructose catabolic pathways would be the same in both species.

In this paper we present evidence that in $R$. sphaeroides fructose was catabolized by the concomitant operation of both the EMP and the EDP. The distribution of fructose carbon into the EMP and the EDP was altered by changing the growth conditions, since fructoseI,6-bisphosphate (FBP) aldolase activity was high under phototrophic growth conditions, but was repressed under aerobic growth conditions. Glucose, on the other hand, was always catabolized via the EDP, irrespective of the growth conditions. 


\section{METHODS}

Organisms and growth conditions. Rhodopseudomonas sphaeroides strain ATCCI 7023, DSMI 58, R. sphaeroides strain 1760-I (lacking 6-phosphogluconate dehydratase), DSMI59, and $R$. capsulata strain KbI, DSMI55, were obtained from the Deutsche Sammlung für Mikroorganismen, Göttingen, W. Germany. The bacteria were cultivated as described previously (Conrad \& Schlegel, 1977). The growth medium of $R$. sphaeroides was supplemented with 0.01 or $0.05 \%(\mathrm{w} / \mathrm{v})$ yeast extract.

Preparation of bacterial extracts. Bacteria were broken by ultrasonication and extracts for enzyme assays were prepared as described by Conrad \& Schlegel (1977). For the assay of FBP aldolase in the strict absence of oxygen, the extract was prepared under an atmosphere of nitrogen. For the assay of gluconate dehydratase, the crude extract was centrifuged at $20000 \mathrm{~g}$ for $30 \mathrm{~min}$ only. For the assay of acid phosphatase, bacteria were suspended in $40 \mathrm{mM}-\mathrm{KCl}$ plus $10 \mathrm{mM}$-triethanolamine/ $\mathrm{HCl}$ buffer $(\mathrm{pH} 7 \cdot 6)$, followed by ultrasonication and centrifugation (20000 $\left.\mathrm{g}, 4{ }^{\circ} \mathrm{C}, 30 \mathrm{~min}\right)$.

Enzyme assays. The majority of the enzyme assays were those used by Conrad \& Schlegel (1977). Acid phosphatase (EC 3.1.3.2; orthophosphoric-monoester phosphohydrolase, acid optimum) was determined in $25 \mathrm{mM}$-maleate buffer (pH 6.2) containing $10 \mathrm{mM}^{-} \mathrm{MgCl}_{2}$ and $10 \mathrm{mM}-6$-phosphogluconate, measuring the formation of inorganic phosphate (Taussky \& Shorr, 1953). Gluconate dehydratase (EC 4.2.1.39; D-gluconate hydro-lyase) was assayed according to Andreesen \& Gottschalk (1969) in $100 \mathrm{mM}-\mathrm{Tris} / \mathrm{HCl}$ buffer ( $\mathrm{pH} \mathrm{7.6)}$ containing $10 \mathrm{mm-sodium} \mathrm{gluconate;} \mathrm{the} \mathrm{formation} \mathrm{of} \mathrm{2-keto-3-deoxygluconate} \mathrm{(KDG)} \mathrm{was}$ measured by the thiobarbituric acid method (Weissbach \& Hurwitz, 1959). KDG kinase (EC 2 . 7 . I .45; ATP: 2-keto-3-deoxy-D-gluconate 6-phosphotransferase) was assayed according to Bender \& Gottschalk (I973) in a mixture containing: $0.725 \mathrm{ml} 50 \mathrm{mM}$-triethanolamine/ $\mathrm{HCl}$ buffer (pH 7.6), $30 \mu 1 \mathrm{l}$ 100 mM- $\mathrm{MgCl}_{2}, 20 \mu 1$ 15 mM-NADH, $50 \mu 130$ mM-ATP, I00 $\mu 160$ mM-KDG (sodium salt), I $5 \mu 1$ (0.9 units) 2-keto-3-deoxy-6phosphogluconate (KDPG) aldolase, 10 $\mu \mathrm{l}$ (20 units) lactate dehydrogenase and $50 \mu \mathrm{l}$ bacterial extract. To measure FBP aldolase (EC 4.I.2.13; D-fructose-I,6-bisphosphate D-glyceraldehyde-3-phosphate-lyase) under anaerobic test conditions, the assay mixture was dispensed into cuvettes which were closed with rubber serum stoppers and flushed with moistened $\mathrm{N}_{2}$ for about $10 \mathrm{~min}$. In some cases $8 \mathrm{~mm}$-cysteine and/or $0.8 \mathrm{~mm}-\left(\mathrm{NH}_{4}\right)_{2} \mathrm{Fe}\left(\mathrm{SO}_{4}\right)_{2}$ were added to the assay mixture. The reaction was started by addition of fructose I,6-bisphosphate.

Radiorespirometry. Radiorespirometric experiments were carried out as described by Conrad \& Schlegel (1977). The washed bacteria were resuspended in mineral medium containing $0.01 \%$ yeast extract to an extinction at $650 \mathrm{~nm}$ of 2 or 3 .

Incorporation of specifically-labelled glucose or fructose into spheroidene. Bacteria were grown under phototrophic conditions in mineral medium containing $5 \mathrm{~mm}-\mathrm{NaHCO}_{3}$ and $5 \mathrm{~mm}$-glucose or fructose specificallylabelled with ${ }^{14} \mathrm{C}$. After 2 to 3 days the bacteria were harvested and the spheroidene fractions were prepared according to the descriptions of Liaaen-Jensen (1962) and Schmidt, Pfennig \& Liaaen-Jensen (I965). The resulting diethyl ether extracts, which contained non-saponifiable pigments, were analysed for radioactivity and spheroidene content. Radioactivity was detected in a liquid scintillation counter, using toluene containing 2,5-diphenyloxazole $\left(4 \mathrm{~g}^{-1}\right)$ and 2,2'-p-phenylene-bis-(4-methyl-5-phenyloxazole) $\left(0 \cdot \mathrm{I}^{\mathrm{g}} \mathrm{1}^{-1}\right)$ as scintillation cocktail. An external standard was used to correct for colour-quenching. The absorption maximum at $542 \mathrm{~nm}$ of the ether extracts was used to calculate the spheroidene concentration assuming an extinction coefficient of $E_{\mathrm{lcm}}^{1 \%}=2600$ (Eimhjellen \& Liaaen-Jensen, 1964). Samples of the ether extracts were chromatographed on silica gel thin-layer plates (Merck; $0.1 \mathrm{~mm}$ thickness) using light petroleum (b.p. 40 to $\left.60^{\circ} \mathrm{C}\right) /$ acetone $(9: \mathrm{I}, \mathrm{v} / \mathrm{v})$ as solvent. The radioactivity on the thin-layer plates was detected with a chromatogram scanner.

Incorporation of $\left[\mathrm{I}^{-14} \mathrm{C}\right]$ fructose and $\left[\mathrm{U}^{14} \mathrm{C}\right]$ fructose into alanine and valine. Bacteria were grown in $50 \mathrm{ml}$ mineral medium containing $0.01 \%$ yeast extract and I mM- $\left[{ }^{14} \mathrm{C}\right]$ fructose (about $6 \mu \mathrm{Ci}$ ); for phototrophic growth, they were incubated in completely filled glass bottles at $500 \mathrm{~lx}$ illumination; for aerobic growth, they were incubated in Erlenmeyer flasks on a rotary shaker ( $150 \mathrm{rev} . \mathrm{min}^{-1}$ ). Alanine and valine were isolated from the bacteria and decarboxylated by the method of Fraenkel \& Levisohn (1967) with the following modifications. The amino acids were isolated by chromatography on silica gel thin-layer plates (Machery and Nagel, G-HR; 0.I mm thickness) using the following solvent systems (Pataki, I966): chloroform/ methanol $/ 17 \%$ (w/w) aq. $\mathrm{NH}_{3}(2: 2: 1$, by vol.), phenol/water $(75: 25, \mathrm{w} / \mathrm{w})$ containing $0.02 \%(\mathrm{w} / \mathrm{v}) \mathrm{NaCN}$ and butan-I-ol/glacial acetic acid/water (4:I : I, by vol.). After each run, the bands co-migrating with radioactive alanine and valine standards were eluted with water and rechromatographed in the subsequent solvent system. The radioactive amino-acid bands were detected by 2 days autoradiography using X-ray film. After decarboxylation of the isolated alanine and valine the released ${ }^{14} \mathrm{CO}_{2}$ was precipitated as $\mathrm{Ba}^{14} \mathrm{CO}_{3}$ which was centrifuged and washed free of contaminating radioactive aldehyde with $4 \mathrm{ml}$ acetone. The washed $\mathrm{Ba}^{14} \mathrm{CO}_{3}$ was then dissolved in $0.5 \mathrm{ml}$ of a solution of $10 \%(\mathrm{w} / \mathrm{v})$ EDTA in I M-Tris/HCl buffer (pH 9) (Hinks, Mills \& Setchell, 1966) and transferred with two water washes $(0.5 \mathrm{ml}$ each) into $10 \mathrm{ml}$ Aquasol. 
Chemicals. These were obtained from the same sources as described previously (Conrad \& Schlegel, 1977). KDG (sodium salt) was a gift from Dr R. Bender. $\left[\mathrm{I}^{14} \mathrm{C}\right] \mathrm{Alanine}$ and $\left[\mathrm{I}^{14} \mathrm{C}\right]$ valine were purchased from Amersham-Buchler, Braunschweig, W. Germany.

\section{RESULTS}

\section{Essential enzymes of sugar catabolism}

The enzymes of two strains of $R$. sphaeroides were analysed in extracts of bacteria grown aerobically or photrophically on malate, glucose or fructose (Table I). The two strains differed with respect to 6-phosphogluconate (6-PG) dehydratase activity: this could not be detected in $R$. sphaeroides strain $1760-\mathrm{I}$, but was easily detected in $R$. sphaeroides strain ATCCI7023. Rhodopseudomonas sphaeroides strain I760-I was therefore designated as the 6-PG dehydratase- ${ }^{-}$strain.

Neither of the two strains possessed an NADP-dependent 6-PG dehydrogenase. The 6-PG dehydratase- ${ }^{-}$strain also lacked NAD-dependent 6-PG dehydrogenase activity, but this activity was detectable in the other strain (containing 6-PG dehydratase); however, the reaction had a lag period of about $10 \mathrm{~min}$ and was completely abolished when $10 \mathrm{mM}-\mathrm{NaF}$, an inhibitor of 6-PG dehydratase, was added. It was therefore concluded that during the reaction 6-PG was converted to pyruvate and glyceraldehyde 3-phosphate by the action of 6-PG dehydratase and KDPG aldolase, which were also present in the extract, and that the apparent NAD-dependent 6-PG dehydrogenase activity was due to glyceraldehyde3-phosphate dehydrogenase; the same side reaction has been demonstrated for Pseudomonas species (Blevins, Feary \& Phibbs, 1975; Phibbs \& McNamee, 1976; Sawyer et al., 1977a).

Rhodopseudomonas sphaeroides ATCCI7023 contained constitutive activities of glucokinase, fructokinase, phosphoglucose isomerase and fructose I,6-bisphosphatase, together with glucose-6-phosphate (G-6-P) dehydrogenase, 6-PG dehydratase and KDPG aldolase. These last three enzyme activities were about 3 to Io-fold higher in glucose- and fructosegrown bacteria, enabling $R$. sphaeroides to catabolize both glucose and fructose via the EDP. While 6-phosphofructokinase activity was low, I-phosphofructokinase activity was induced 10 to 20 -fold by fructose; as a phosphofructomutase activity converting fructose I-phosphate (F-I-P) to fructose 6-phosphate (F-6-P) could not be detected, fructose was assumed to be catabolized via F-I-P and the EMP. The FBP aldolase activity detected was only very low, but this was attributed to the non-optimal assay conditions: Willard, Schulman \& Gibbs (1965) have demonstrated much higher activities by adding cysteine and ferrous ions to the assay mixture (see below).

The activities of all the enzymes tested were about 2 to Io-fold lower in phototrophicallygrown bacteria than in aerobically-grown bacteria. Such a decrease of activity under phototrophic growth conditions has previously been observed for G-6-P dehydrogenase, 6-PG dehydratase and KDPG aldolase and has been discussed in terms of catabolite repression (Ohmann et al., 1969).

\section{Radiorespirometric experiments}

Radiorespirometric experiments were carried out with glucose and fructose labelled with ${ }^{14} \mathrm{C}$ in the $\mathrm{I}^{-}, 2-, 3-, 3,4-$ and 6-positions and with $\left[\mathrm{U}-{ }^{14} \mathrm{C}\right]$ glucose and [U-14 $\left.\mathrm{C}\right]$ fructose. The ${ }^{14} \mathrm{CO}_{2}$ released from a specifically-labelled hexose was trapped in $\mathrm{KOH}$ and counted. The percentage yield of ${ }^{14} \mathrm{CO}_{2}$ originating from the radioactive hexose was determined.

Bacteria grown under aerobic conditions on the corresponding sugar were used for these experiments. Similar patterns of radiorespirometric data were obtained with either glucose or fructose as substrate (Fig. I). With both substrates, the highest rates of ${ }^{14} \mathrm{CO}_{2}$ evolution were obtained on $\left[\mathrm{I}^{14} \mathrm{C}\right]$ - and $\left[4^{-{ }^{14}} \mathrm{C}\right]$ hexose, while ${ }^{14} \mathrm{CO}_{2}$ evolution from $\left[2-{ }^{14} \mathrm{C}\right]-,\left[3^{-14} \mathrm{C}\right]-$ 
Table I. Enzymes of sugar metabolism in extracts of $R$. sphaeroides

Specific activities of enzymes are expressed as nmol $\mathrm{min}^{-1}$ (mg protein) $)^{-1}$.

\begin{tabular}{|c|c|c|c|c|c|c|c|c|c|c|c|}
\hline \multirow[b]{3}{*}{ Enzyme } & \multicolumn{6}{|c|}{ Strain ATCCI 7023: substrates and growth conditions } & \multicolumn{5}{|c|}{ Strain $1760-1 \|:$ substrates and growth conditions } \\
\hline & \multicolumn{2}{|c|}{ Malate } & \multicolumn{2}{|c|}{ Glucose } & \multicolumn{2}{|c|}{ Fructose } & \multicolumn{2}{|c|}{ Malate } & \multirow{2}{*}{$\begin{array}{l}\text { Glucose } \\
\text { Photo- } \\
\text { trophic } \dagger\end{array}$} & \multicolumn{2}{|c|}{ Fructose } \\
\hline & Aerobic* & $\begin{array}{l}\text { Photo- } \\
\text { trophic } \dagger\end{array}$ & Aerobic* & $\begin{array}{l}\text { Photo- } \\
\text { trophic } \dagger\end{array}$ & Aerobic* & $\begin{array}{l}\text { Photo- } \\
\text { trophic } \dagger\end{array}$ & Aerobic* & $\begin{array}{l}\text { Photo- } \\
\text { trophic } \dagger\end{array}$ & & Aerobic* & $\begin{array}{l}\text { Photo- } \\
\text { trophic } \dagger\end{array}$ \\
\hline Glucokinase & 85 & & 86 & & 83 & & 38 & & & 44 & \\
\hline Fructokinase & 26 & & 29 & & 31 & & I6 & & & 8 & \\
\hline $\begin{array}{l}\text { Phosphoglucose } \\
\text { isomerase }\end{array}$ & 322 & & II 26 & & 1239 & & 810 & & & 1361 & \\
\hline Phosphofructomutase & & & & & ND & ND & & & & & \\
\hline $\begin{array}{l}\text { Glucose-6-phosphate } \\
\text { dehydrogenase } \\
\text { 6-Phosphogluconate } \\
\text { dehydrogenase }\end{array}$ & $3 I$ & 10 & 262 & 34 & 320 & 17 & 140 & 12 & 133 & 388 & 145 \\
\hline NADP & $<\mathrm{I}$ & & $<\mathrm{I}$ & & $<\mathrm{I}$ & & ND & ND & ND & ND & ND \\
\hline NAD $\ddagger$ & 8 & & 25 & & 23 & & ND & ND & ND & ND & ND \\
\hline 6-Phosphogluconate & 24 & & 263 & & 269 & & ND & & & ND & ND \\
\hline $\begin{array}{l}\text { dehydratase } \\
\text { KDPG aldolase }\end{array}$ & 172 & $10 \S$ & 702 & $162 \S$ & 947 & $118 \S$ & 195 & ND§ & $\int \mathrm{ND} \S$ & 702 & 253 \\
\hline $\begin{array}{l}\text { I-Phosphofructo- } \\
\text { kinase }\end{array}$ & $\begin{array}{r}172 \\
16\end{array}$ & 2 & $\begin{array}{r}792 \\
18\end{array}$ & 2 & $\begin{array}{l}947 \\
354\end{array}$ & 47 & $\begin{array}{r}193 \\
14\end{array}$ & 2 & 2 & 122 & 40 \\
\hline $\begin{array}{l}\text { 6-Phosphofructo- } \\
\text { kinase }\end{array}$ & 25 & 2 & 19 & 5 & 30 & 3 & & 3 & 7 & & \\
\hline FBP aldolase & 2 & & $<2$ & & 3 & 10 & I & & & 2 & 8 \\
\hline Fructose & 14 & & 12 & & 18 & & 5 & & & 15 & 6 \\
\hline
\end{tabular}

ND, Not detectable.

* The mineral medium contained $0.01 \%$ yeast extract.

$\dagger$ The mineral medium contained $0.05 \%$ yeast extract.

$\$$ The activity was completely abolished by addition of $10 \mathrm{mM}-\mathrm{NaF}$.

\& 6-Phosphogluconate dehydratase and KDPG aldolase were measured together in a combined assay (Gottschalk, Eberhardt \& Schlegel, 1964).

|| 6-PG dehydratase- strain. 


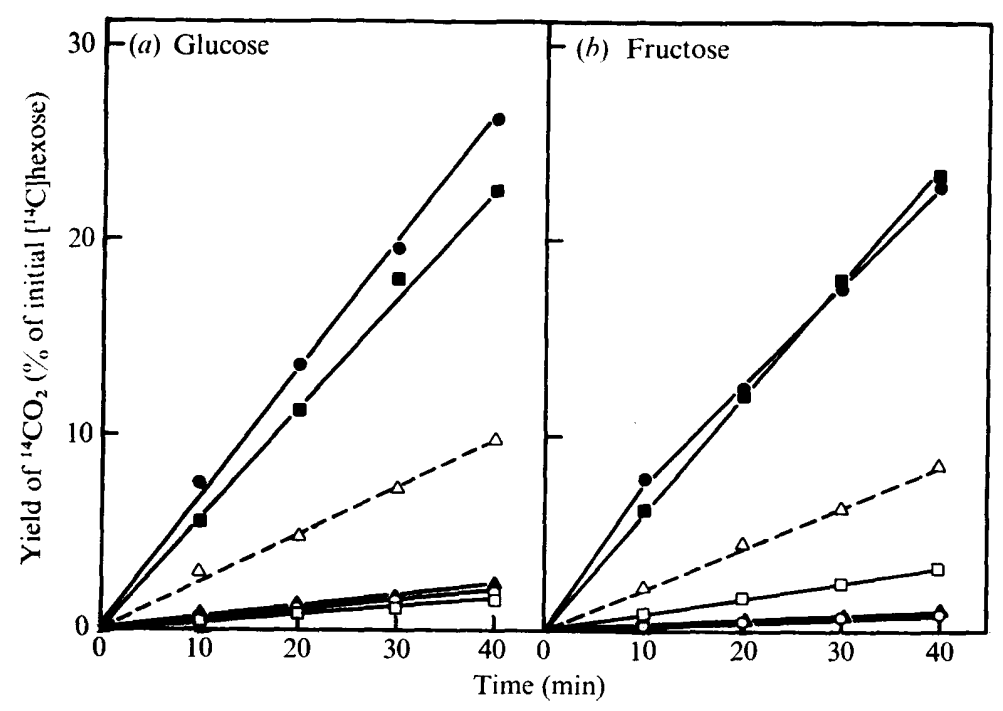

Fig. I. Radiorespirometry of specifically-labelled glucose and fructose by $R$. sphaeroides strain ATCCI7023. Each incubation mixture contained $0.8 \mathrm{ml}$ resuspended bacteria $\left(E_{650}=2\right)$ grown aerobically on glucose or fructose and $0.2 \mathrm{ml}$ glucose or fructose (10 $\mu \mathrm{mol} \mathrm{ml}^{-1}$ ) labelled in different carbon atoms. Substrates and their radioactivities (d.p.m.) were: (a) [I-14 C]glucose, $1 \cdot 92 \times 10^{5}$;

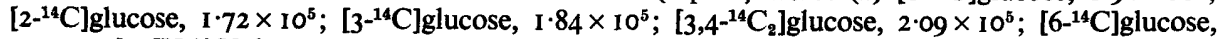
$1.92 \times 10^{5}$; [U-14 C]glucose, $1.79 \times 10^{5}$. (b) [1 ${ }^{14} \mathrm{C}$ fructose, $\mathrm{I} \cdot 44 \times 10^{5} ;\left[2-{ }^{14} \mathrm{C}\right.$ ]fructose, $1.5 \mathrm{I} \times 10^{5}$; $\left[3^{-14} \mathrm{C}\right.$ ]fructose, $\mathrm{r} \cdot 63 \times 10^{5} ;\left[3,4^{-14} \mathrm{C}_{2}\right]$ fructose, $\mathrm{I} \cdot 77 \times 10^{5} ;\left[6{ }^{14} \mathrm{C}\right]$ fructose, $0.68 \times 10^{5} ;$ [U.- $\left.{ }^{14} \mathrm{C}\right]$ fructose, $1.74 \times 10^{5}$.

, [I $\left.1-^{14} \mathrm{C}\right]$ hexose; $\mathrm{O},\left[{ }^{2-{ }^{14}} \mathrm{C}\right]$ hexose; $\square,\left[3^{14} \mathrm{C}\right]$ hexose; $\square,\left[4^{14} \mathrm{C}\right]$ hexose; $\Delta,\left[6-{ }^{14} \mathrm{C}\right]$ hexose; $\triangle$, [U-14 $\mathrm{C}]$ hexose. The rate of ${ }^{14} \mathrm{CO}_{2}$ evolution from $\left[4^{-14} \mathrm{C}\right]$ hexose was calculated by difference from the rates obtained from $\left[3,4^{-14} \mathrm{C}_{2}\right]$ hexose and $\left[3^{-14} \mathrm{C}\right]$ hexose.

and $\left[6-{ }^{14} \mathrm{C}\right]$ hexose was quite low. This result indicated that both glucose and fructose were degraded via the EDP. Less ${ }^{14} \mathrm{CO}_{2}$ was released from $\left[\mathrm{I}^{14} \mathrm{C}\right]$ fructose than from $\left[{ }^{[-}{ }^{14} \mathrm{C}\right]-$ glucose and significantly more ${ }^{14} \mathrm{CO}_{2}$ was released from $\left[3^{-14} \mathrm{C}\right]$ fructose than from $\left[3^{-14} \mathrm{C}\right]$ glucose, indicating that a small part of the fructose was catabolized via the EMP. The radiorespirometric experiments did not indicate any participation of the pentose phosphate pathway in sugar degradation, which is consistent with the observation that 6-PG dehydrogenase was absent from extracts of $R$. sphaeroides.

To confirm the surprising result that fructose was catabolized via the EDP even though I-phosphofructokinase was induced, the radiorespirometric experiments were repeated with bacteria cultivated under phototrophic conditions. Since the experimental conditions for radiorespirometry were aerobic, the rates of ${ }^{14} \mathrm{CO}_{2}$ evolution from $\left[\mathrm{U}-{ }^{14} \mathrm{C}\right]$ hexose were lower (about $60 \%$ ) with phototrophically- than with aerobically-grown bacteria. The yields of

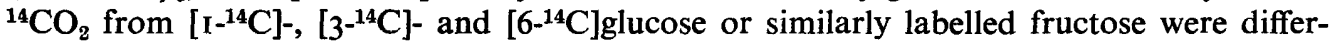
entially plotted against the yields of $\left[\mathrm{U}^{14} \mathrm{C}\right]$ glucose or $\left[\mathrm{U}-{ }^{14} \mathrm{C}\right]$ fructose, so that the data obtained for phototrophically-grown bacteria could be compared directly with those obtained for aerobically-grown organisms (Fig. 2).

Using $\left[\mathrm{I}^{14} \mathrm{C}\right]$ - and $\left[3^{-14} \mathrm{C}\right] \mathrm{glucose}$, the differential rates of ${ }^{14} \mathrm{CO}_{2}$ evolution were identical in both cell types, suggesting that the growth conditions had no influence on the ability of the bacteria to catabolize glucose via the EDP (Fig. 2a). Using labelled fructose, however, the differential rates of ${ }^{14} \mathrm{CO}_{2}$ evolution in phototrophically-grown bacteria compared with those in aerobically-grown bacteria were higher on $\left[3^{-14} \mathrm{C}\right]$ fructose and lower on $\left[\mathrm{I}^{-14} \mathrm{C}\right]-$ fructose (Fig. $2 b$ ). Thus the ability of the bacteria to catabolize fructose via the EMP was higher under phototrophic than under aerobic growth conditions. There was no difference 


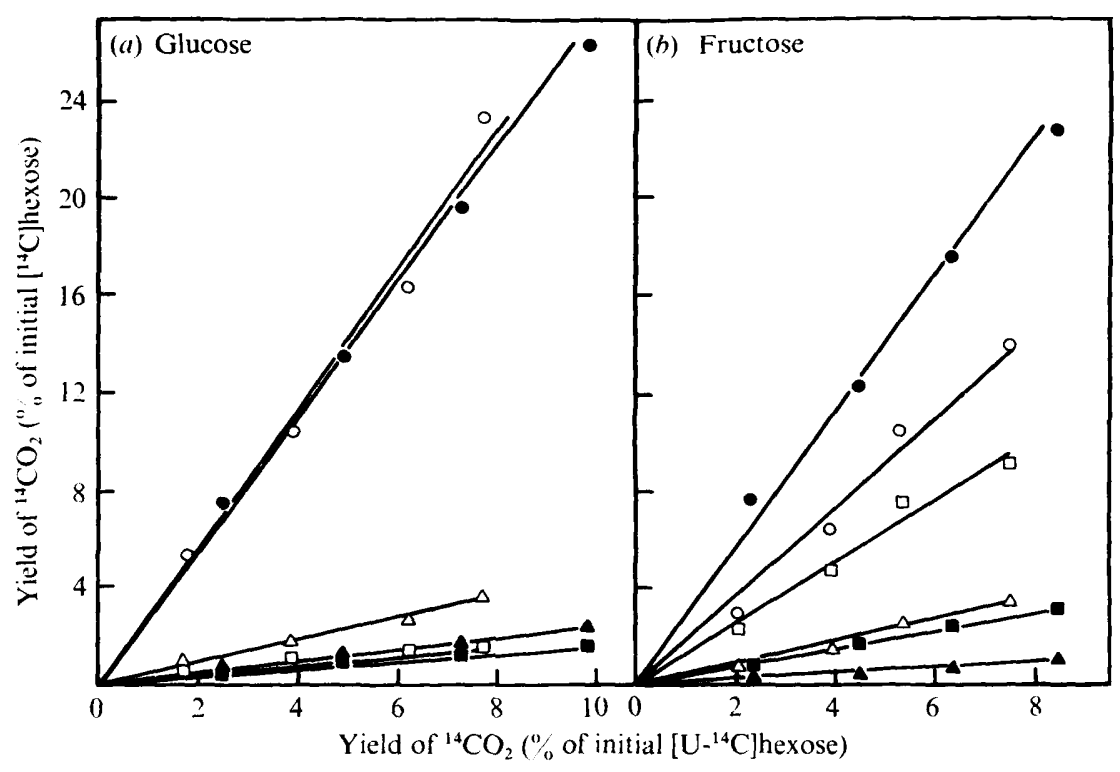

Fig. 2. Comparison between radiorespirometric data obtained with aerobically- and phototrophically-grown cells of $R$. sphaeroides strain ATCC17023. The radiorespirometric data for aerobically-grown bacteria are those of Fig. 1 . The incubation mixture for the experiment with phototrophically-grown bacteria was similar to that of Fig. I. Substrates and their radioactivities (d.p.m.) were: (a) $\left[\mathrm{I}^{14} \mathrm{C}\right]$ glucose, $1 \cdot 74 \times 10^{5} ;\left[3^{-14} \mathrm{C}\right]$ glucose, $\mathrm{I} \cdot 83 \times 10^{5} ;\left[6-{ }^{14} \mathrm{C}\right]$ glucose, $1 \cdot 69 \times 10^{5}$; [U-14 C]glucose, $\mathrm{I} \cdot 50 \times 10^{5}$. (b) $\left[\mathrm{I}^{14} \mathrm{C}\right]$ fructose, $2.03 \times 10^{5} ;\left[3^{-14} \mathrm{C}\right]$ fructose, $\mathrm{I} \cdot 80 \times 10^{5} ;\left[6-{ }^{14} \mathrm{C}\right]-$ fructose, $0.67 \times 10^{5} ;\left[U_{-14}{ }^{14} \mathrm{C}\right]$ fructose, $2.52 \times 10^{5}$.

Open symbols, phototrophically-grown bacteria; closed symbols, aerobically-grown bacteria;

$\bullet, \bigcirc,\left[I^{-14} \mathrm{C}\right]$ hexose; $\square, \square,\left[3^{-14} \mathrm{C}\right]$ hexose; $\Delta, \Delta,\left[6-{ }^{14} \mathrm{C}\right]$ hexose.

between aerobically- and phototrophically-grown bacteria in the relative yields ${ }^{14}{ }^{14} \mathrm{CO}_{2}$ released from position 2 or 4 of either glucose or fructose (not shown). With both hexoses, however, the differential rates of ${ }^{14} \mathrm{CO}_{2}$ evolution from position 6 were about 2 to 4 -fold higher in bacteria grown phototrophically than in those grown aerobically. This higher rate suggested that some of the intermediate triose phosphate was recycled via FBP to G-6-P, thus enabling C-6 of the original substrate to become C-I of G-6-P.

\section{Experiments with the 6-PG dehydratase- strain of Rhodopseudomonas sphaeroides}

Since fructose was catabolized via the EDP in aerobically-grown $R$. sphaeroides, it was interesting to see by which pathway fructose would be catabolized in the 6-PG dehydratasestrain, which lacked a functional EDP. A radiorespirometric experiment was carried out using specifically-labelled fructose and aerobically-grown bacteria of the 6-PG dehydratasestrain (Fig. 3). The rates of ${ }^{14} \mathrm{CO}_{2}$ evolution from the different positions of fructose were in the order $\mathrm{C}-4 \gg \mathrm{C}-3>\mathrm{C}-\mathrm{I}>\mathrm{C}-2=\mathrm{C}-6$. This result indicated that fructose was predominantly catabolized via the EMP; however, the significant release of ${ }^{14} \mathrm{CO}_{2}$ from position $\mathrm{I}$ and the rate of ${ }^{14} \mathrm{CO}_{2}$ evolution with $\mathrm{C}-4 \gg \mathrm{C}-3$ suggested that a significant part of the fructose was degraded via a pathway similar to the EDP.

This suggestion was confirmed by demonstrating all the enzymes necessary for the operation of the KDG-bypass, first described for $R$. sphaeroides by Szymona \& Doudoroff (I960). The deficient 6-PG dehydratase is bypassed by the reaction:

$$
\text { 6-PG } \stackrel{\text { acid phosphatase }}{\longrightarrow} \text { gluconate } \stackrel{\text { gluconate dehydratase }}{\longrightarrow} \text { KDG } \stackrel{\text { KDG kinase }}{\longrightarrow} \text { KDPG }
$$




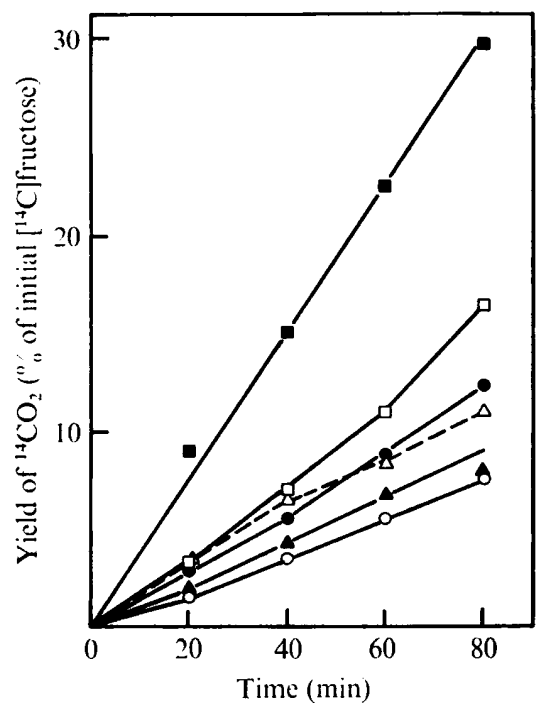

Fig. 3. Radiorespirometry of specifically-labelled fructose by $R$. sphaeroides strain I760-I (6-PG dehydratase $\left.{ }^{-}\right)$. Each incubation mixture contained $0.8 \mathrm{ml}$ resuspended bacteria $\left(E_{650}=3\right)$ grown aerobically on fructose and $0.2 \mathrm{ml}$ fructose (10 $\mu \mathrm{mol} \mathrm{ml}^{-1}$ ) labelled in different carbon atoms. Substrates and their radioactivities (d.p.m.) were: $\left[\mathrm{I}^{14} \mathrm{C}\right]$ fructose, $1 \cdot 42 \times 10^{5} ;\left[2-{ }^{14} \mathrm{C}\right]$ fructose, $1.49 \times 10^{5} ;\left[3{ }^{14} \mathrm{C}\right]$ fructose, $1 \cdot 65 \times 10^{5} ;\left[3,4{ }^{14} \mathrm{C}_{2}\right]$ fructose, $1.80 \times 10^{5} ;\left[6-{ }^{14} \mathrm{C}\right]$ fructose, $0.67 \times 10^{5}$; $\left[\mathrm{U}^{14} \mathrm{C}\right]$ fructose, $\mathrm{I} \cdot 75 \times 10^{5}$. The symbols are the same as in Fig. I.

The following enzyme activities were measured in bacteria grown aerobically on fructose [nmol $\mathrm{min}^{-1}$ (mg protein) ${ }^{-1}$ ]: acid phosphatase [48]; gluconate dehydratase [I9I]; KDG kinase [7]. The activity of the KDG kinase was rather low, but it correlated well with the relatively high doubling time of the 6-PG dehydratase- strain growing aerobically on fructose (Table 2). Almost no growth occurred aerobically on glucose indicating that the KDG-bypass was the only route for glucose degradation.

When growing phototrophically on fructose, both strains of $R$. sphaeroides had the same low doubling time of $4.5 \mathrm{~h}$ (Table 2). Under all the other growth conditions, the doubling times were 3 to ro times higher for the 6-PG dehydratase ${ }^{-}$strain than for the other strain. This result indicated that a functional EDP was not necessary for fructose catabolism under phototrophic conditions, while it was essential for fructose catabolism under aerobic conditions and for glucose catabolism under both aerobic and phototrophic conditions.

\section{Incorporation of specifically-labelled hexose into spheroidene}

In contrast to the experimental conditions for radiorespirometry, which are always aerobic, the incorporation of specifically-labelled hexose into carotenoids can be carried out under phototrophic conditions. As acetyl-CoA is the precursor of the carotenoids, radioactivity from a specifically-labelled hexose is only incorporated when the labelled position is not lost as ${ }^{14} \mathrm{CO}_{2}$ during hexose breakdown, either in the 6-PG dehydrogenase reaction or in the pyruvate dehydrogenase reaction. Rhodopseudomonas sphaeroides and $\boldsymbol{R}$. capsulata both contain almost exclusively spheroidene as carotenoid with little spheroidenone and neurosporene (Eimhjellen \& Liaaen-Jensen, 1964).

Rhodopseudomonas capsulata, used as a reference bacterium with known hexose catabolic pathways (Conrad \& Schlegel, I977), and $R$. sphaeroides were grown under phototrophic conditions on $\left[\mathrm{I}^{14} \mathrm{C}\right]-,\left[3^{-14} \mathrm{C}\right]-$ and $\left[6-{ }^{14} \mathrm{C}\right]$ glucose or similarly labelled fructose, and their ether-soluble non-saponifiable extracts (spheroidene fractions) were analysed for radioactivity and spheroidene content (not shown). The spheroidene fractions of both bacteria 
Table 2. Doubling times of $R$. sphaeroides under different growth conditions

Doubling time (h)

Growth condition

Strain ATCCI $7023 \quad$ Strain $1760-I^{*}$

Aerobic

Glucose

Glucose

4

39

Fructose

15

Phototrophic

Fructose
*6-PG dehydratase
 strain. $^{4 \cdot 5}$

had significantly lower specific radioactivities when the organisms were grown on either $\left[\mathrm{I}^{14} \mathrm{C}\right]$ glucose or $\left[3^{-14} \mathrm{C}\right]$ fructose, than after growth on hexose labelled in another position. This result was consistent with glucose being catabolized mainly via the EDP and fructose mainly via the EMP. However, thin-layer chromatography of the spheroidene fractions revealed that in both bacteria most of the radioactivity co-migrated with three unidentified compounds and only a lesser part with spheroidene, spheroidenone and neurosporene.

\section{Incorporation of $\left[U-{ }^{14} C\right]$ fructose and $\left[I^{14} C\right]$ fructose into alanine and valine}

To get further evidence for fructose being catabolized via the EMP under phototrophic conditions and via the EDP under aerobic conditions, $R$. sphaeroides was grown on $\left[\mathrm{U}^{14} \mathrm{C}\right]-$ and $\left[\mathrm{I}^{14} \mathrm{C}\right]$ fructose under both conditions, and alanine and valine were isolated from the cell protein and analysed for the percentage radioactivity present in their carboxyl groups. Both amino acids are derivatives of pyruvate; their labelling pattern can therefore be used to calculate the percentage radioactivity in the carboxyl group of pyruvate (Fig. 4). The percentage radioactivity in the carboxyl group of alanine would be expected to be the same as that in its precursor pyruvate, whereas the percentage radioactivity in the carboxyl group of valine would be expected to be less than that in pyruvate as half of the radioactivity is lost as ${ }^{14} \mathrm{CO}_{2}$ during the biosynthesis of valine.

The percentage radioactivity in the carboxyl groups of alanine and valine originating from $\left[\mathrm{U}-{ }^{14} \mathrm{C}\right]$ fructose was less than the theoretical values of $33.3 \%$ and $20 \cdot 0 \%$, respectively. This loss of radioactivity was due to a systematic error and was explained by the incomplete recovery of ${ }^{14} \mathrm{CO}_{2}$ after decarboxylation of the amino acids: $\left[\mathrm{I}^{14} \mathrm{C}\right]$ alanine and $\left[\mathrm{I}^{-14} \mathrm{C}\right] \mathrm{valine}$ yielded only 83 to $86 \%$ of the radioactivity in their carboxyl groups (Table 3). The relative deviation from the expected value was used to correct the data obtained with alanine and valine originating from $\left[\mathrm{I}^{14} \mathrm{C}\right]$ fructose. Aerobically growing bacteria incorporated the label from $\left[\mathrm{I}^{14} \mathrm{C}\right]$ fructose into the carboxyl groups of alanine and valine to a higher extent than did phototrophically growing bacteria (Table 3). Calculating the percentage radioactivity in the carboxyl group of pyruvate, we found for both amino acids about $85 \%$ under aerobic conditions and $30 \%$ under phototrophic conditions. This supports the conclusion that $R$. sphaeroides degraded fructose under phototrophic conditions mainly via the EMP and not via the EDP as under aerobic conditions.

\section{Influence of aerobic and phototrophic growth conditions on the FBP aldolase activity}

The influence of aerobic and phototrophic growth conditions on the fructose catabolic pathway suggested that one of the enzymes of fructose catabolism was altered by the growth conditions. Willard et al. (1965) have shown that the FBP aldolase of $R$. sphaeroides is a metallo-sulphydryl enzyme and its activity is stimulated by the addition of cysteine and/or ferrous ions. They did not point out, however, that when the FBP aldolase activity was tested under optimal conditions it was markedly higher in bacteria grown phototrophically on glucose than in those grown aerobically on glucose. Therefore, we re-examined the proper-

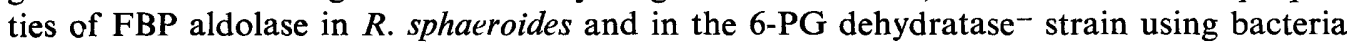




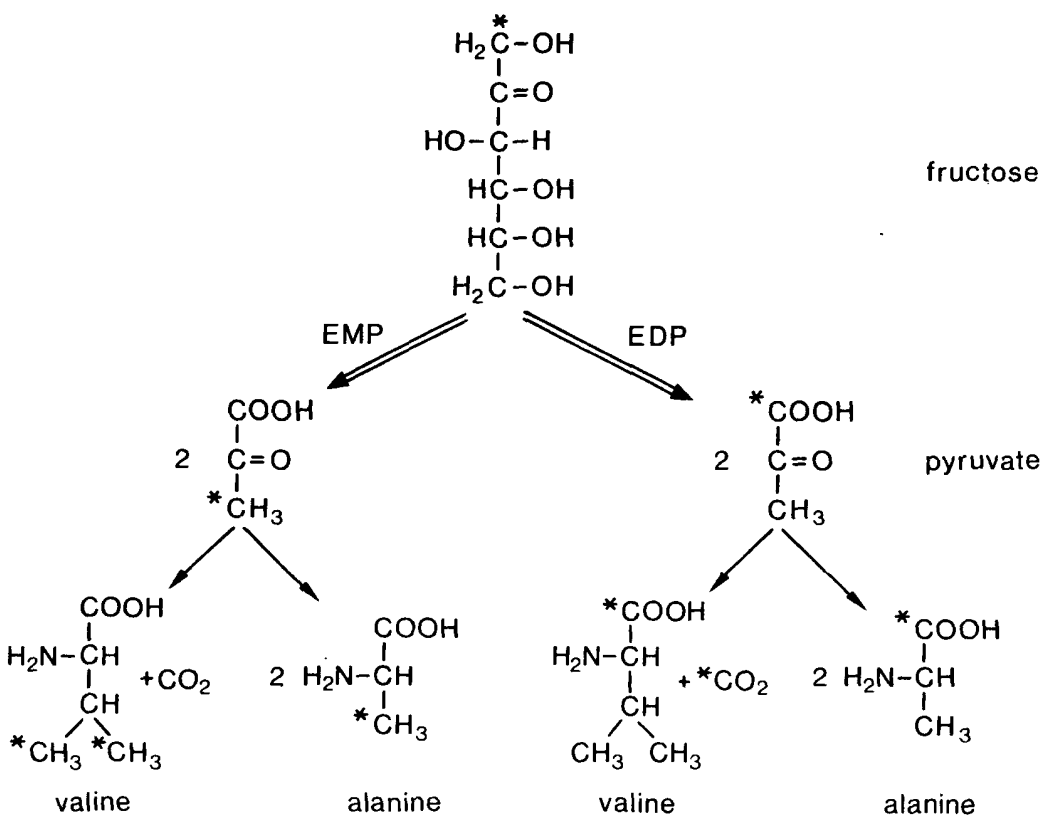

Fig. 4. Incorporation of radioactivity from $\left[\mathrm{I}^{14} \mathrm{C}\right]$ fructose into pyruvate, alanine and valine.

Table 3. Incorporation of $\left[U-{ }^{14} C\right]$ fructose and $\left[{ }^{14} C\right]$ fructose into alanine and valine in $R$. sphaeroides strain ATCCI 7023 grown under aerobic or phototrophic conditions

Growth condition

$\begin{array}{ll}\text { Aerobic } & {\left[\mathrm{U}-{ }^{14} \mathrm{C}\right] \text { fructose }} \\ & {\left[\mathrm{I}^{14} \mathrm{C}\right] \text { fructose }} \\ \text { Phototrophic } & {\left[\mathrm{U}-14^{14} \mathrm{C}\right] \text { fructose }} \\ & {\left[\mathrm{I}^{-{ }^{14}} \mathrm{C}\right] \text { fructose }}\end{array}$

$\left[{ }^{-14} \mathrm{C}\right]$ alanine or -valine

$\overbrace{\begin{array}{c}\text { d.p.m. } \\ \text { in } \\ \text { carboxyl } \\ \text { group* }\end{array}}^{\begin{array}{c}\text { in d.p.m. } \\ \text { carboxyl } \\ \text { group } \\ \text { (cor- } \\ \text { rected) } \neq\end{array}} \begin{gathered}\begin{array}{c}\text { in } \\ \text { carboxyl } \\ \text { group of } \\ \text { pyruvate } \\ \text { (calcu- } \\ \text { lated) } \S\end{array} \\ \text { lanine }\end{gathered}$

$\begin{array}{lll}29 \cdot 4 & 33 \cdot 3 & 33 \cdot 3 \\ 74 \cdot 6 & 84 \cdot 4 & 84 \cdot 4 \\ 27 \cdot 9 & 33 \cdot 3 & 33 \cdot 3 \\ 24.9 & 29 \cdot 7 & 29 \cdot 7\end{array}$

$86 \cdot 3$

\begin{tabular}{|c|c|c|}
\hline \multicolumn{3}{|c|}{ Valine } \\
\hline $\begin{array}{l}\% \text { d.p.m. } \\
\text { in } \\
\text { carboxyl } \\
\text { groupt }\end{array}$ & $\begin{array}{l}\% \text { d.p.m. } \\
\text { in } \\
\text { carboxyl } \\
\text { group } \\
\text { (cor- } \\
\text { rected) } \ddagger\end{array}$ & $\begin{array}{c}\% \text { d.p.m. } \\
\text { in } \\
\text { carboxyl } \\
\text { group of } \\
\text { pyruvate } \\
\text { (calcu- } \\
\text { lated) } \$\end{array}$ \\
\hline
\end{tabular}

$\begin{array}{lll}17 \cdot 1 & 20 \cdot 0 & 33 \cdot 3 \\ 65 \cdot 7 & 76 \cdot 3 & 86.5 \\ 16 \cdot 3 & 20 \cdot 0 & 33 \cdot 3 \\ 14.3 & 17 \cdot 5 & 29 \cdot 8 \\ 83.4 & & \end{array}$

* Mean values from two determinations; the maximum deviation from the mean value was $2.5 \%$.

$\dagger$ Mean values from two determinations; the maximum deviation from the mean value was $5 \%$.

$\ddagger$ The relative deviation from the radioactivity expected in the carboxyl group of alanine or valine derived from $\left[\mathrm{U}_{-14}{ }^{14} \mathrm{C}\right]$ fructose was used to correct the values of alanine or valine derived from $\left[\mathrm{I}^{14} \mathrm{C}\right]$ fructose.

$\S$ The percentage radioactivity in the carboxyl group of pyruvate was expected to be equal to that in the carboxyl group of alanine and was calculated from that in the carboxyl group of valine using $p=200 v /$ $(100+v)$, in which $p$ is the percentage radioactivity in the carboxyl group of pyruvate and $v$ is the percentage radioactivity in the carboxyl group of valine.

grown aerobically or phototrophically on fructose (Table 4). Confirming the results of Willard et al. (1965), we found that the enzyme activity was highest when cysteine and ferrous ions were included into the assay mixture; anaerobic test conditions were essential for obtaining optimal enzyme activities. Using these test conditions, FBP aldolase activity was 20 to 30 -fold higher in phototrophically-grown organisms than in aerobically-grown organisms. Transfer of bacteria growing phototrophically to aerobic conditions resulted in a 


\section{Table 4. Activity of FBP aldolase in extracts of $R$. sphaeroides after aerobic or phototrophic growth on fructose}

FBP aldolase activity was assayed using the standard assay mixture, or with additions of $8 \mathrm{~mm}$-cysteine and/or $0.8 \mathrm{~mm}-\left(\mathrm{NH}_{4}\right)_{2} \mathrm{Fe}\left(\mathrm{SO}_{4}\right)_{2}$ as indicated.

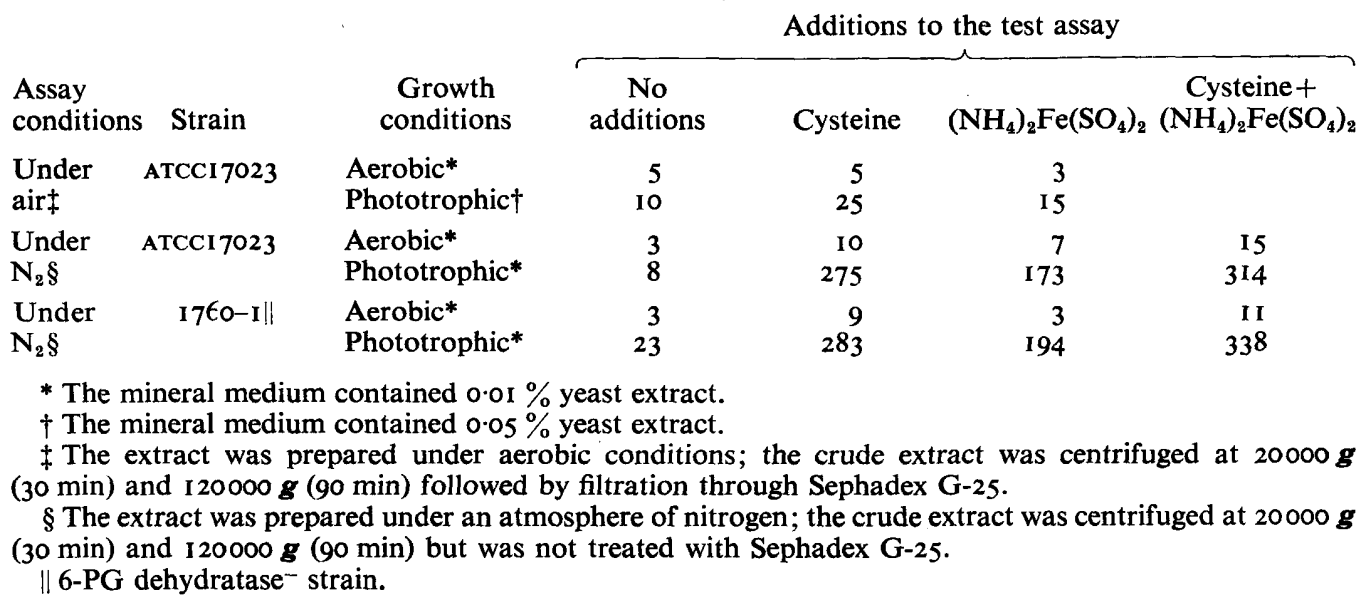

repression of the synthesis of FBP aldolase rather than in an inactivation of enzyme activity (unpublished results).

\section{DISCUSSION}

The quantitative distribution of hexose carbon into the Embden-Meyerhof and pentose phosphate pathways or into the Entner-Doudoroff and pentose phosphate pathways is often influenced by the culture conditions, such as composition of the growth medium (Wang \& Krackov, 1962), temperature (Palumbo \& Witlev, 1969), oxygen partial pressure and $\mathrm{pH}$ (Blumenthal, Huettner \& Montiel, I974), or by the state of cell differentiation (Lynch \& Henney, 1973; Orlowski \& Goldman, 1975; Dawson \& Westlake, 1975). In Streptococcus faecalis, the flow of glucose carbon between the EMP and the pentose phosphate pathway is apparently regulated by the 6-PG dehydrogenase activity, which is modulated by FBP (Brown \& Wittenberger, 1971). The simultaneous function of the EMP and the EDP for the breakdown of glucose or fructose has, to our knowledge, only been demonstrated in Clostridium (Desulfotomaculum) nigrificans (Akagi \& Jackson, 1967), in Thiobacillus A2 (Wood \& Kelly, 1976) and in several species of Pseudomonas (Sawyer et al., I 977 a). However, the simultaneous presence of the enzymes of the two pathways has also been demonstrated in Aquaspirillum gracile (Laughon \& Krieg, 1974), in Bacillus larvae (Julian \& Bulla, I97I), in marine species of Alcaligenes and Pseudomonas marina (Sawyer, Baumann \& Baumann, $1977 b$ ) and in R. capsulata and R. sphaeroides (Conrad \& Schlegel, 1974). Aquaspirillum gracile was believed to catabolize glucose via the EDP and the pentose phosphate pathway, since the FBP aldolase activity was rather low (Laughon \& Krieg, 1974); B. larvae was shown to utilize glucose by an oxidative pathway (Julian \& Bulla, I97I); the marine species of Alcaligenes and $P$. marina catabolized glucose and fructose apparently via the EDP (Sawyer et al., I977b); and $R$. capsulata was demonstrated to catabolize fructose via the EMP and glucose via the EDP (Conrad \& Schlegel, I977). We have now shown that $R$. sphaeroides catabolizes fructose via both pathways together. The distribution of fructose carbon into the EMP and the EDP was regulated by the influence of aerobic and phototrophic growth conditions on the biosynthesis of FBP aldolase.

Labelling experiments with $\left[\mathrm{I}^{-14} \mathrm{C}\right]$ fructose and analysis of the radioactivity in the carboxyl groups of alanine and valine have shown that the major part of the fructose was 
catabolized via the EMP under phototrophic growth conditions and via the EDP under aerobic conditions. The exact proportion of fructose carbon being degraded by one or the other pathway cannot be estimated from the labelling data, since the extent of conversion of triose phosphate to the pyruvate pool is not known. An incomplete conversion of triose phosphate to pyruvate would result in an overestimation of the contribution of the EDP. Assuming, however, that the extent of triose phosphate conversion was the same under both aerobic and phototrophic growth conditions, the contribution of the EDP to fructose degradation was not more than $30 \%$ under phototrophic and not more than $85 \%$ under aerobic conditions.

The results of the amino acid-labelling experiments were confirmed by studying the incorporation of $\left[\mathrm{I}^{14} \mathrm{C}\right]-,\left[3^{-14} \mathrm{C}\right]-$ and $\left[6{ }^{-14} \mathrm{C}\right]$ fructose into the spheroidene fraction of phototrophically growing bacteria. The resulting labelling pattern was characteristic for a major operation of the EMP. The labelling pattern was essentially the same as in a similar experiment with $R$. capsulata, which is known to catabolize fructose via the EMP (Conrad \& Schlegel, 1977). However, our interpretation of the labelling data is only correct if the radioactive compounds within the spheroidene fraction were derived exclusively from acetate or acetyl-CoA.

Further evidence for fructose being degraded under phototrophic conditions mainly via the EMP came from radiorespirometric experiments. Phototrophically-grown bacteria showed an increased ability to catabolize fructose via the EMP, compared with aerobicallygrown bacteria which catabolized fructose predominantly via the EDP. Rhodospirillaceae, like $R$. sphaeroides, $R$. capsulata and Rhodospirillum rubrum, possess the capacity for aerobic electron transport, independent of aerobic or phototrophic growth conditions (Kikuchi, Saito \& Motokawa, 1965; Klemme \& Schlegel, 1969; Thore, Keister \& San Pietro, 1969). This capacity is, in phototrophically-grown bacteria, only about 50 to $70 \%$ less than in aerobically-grown organisms. As the activities of the enzymes involved in sugar catabolism were also lower in phototrophically-grown $R$. sphaeroides, it was impossible to decide whether these enzyme activities or the capacity for aerobic electron transport were rate-limiting for fructose radiorespirometry. We suppose, however, that in phototrophicallygrown bacteria one of the glucolytic enzymes was rate-limiting for radiorespirometry, as a relatively high ${ }^{14} \mathrm{CO}_{2}$ evolution from $\left[6-{ }^{14} \mathrm{C}\right]$ hexose was observed. A high release of ${ }^{14} \mathrm{CO}_{2}$ from position 6 has been explained by recycling of triose phosphate via FBP to G-6-P and has often been found in bacteria which are able to catabolize hexose via the EDP (and, in some cases, the pentose phosphate pathway), like Thiobacillus ferrooxidans (Tabita \& Lundgren, 1971), Neisseria gonorrhoeae (Morse, Stein \& Hines, 1974) and Corynebacterium autotrophicum (R. Opitz, personal communication). The assumption that triose phosphate was recycled because of a rate-limiting glucolytic enzyme accords with the higher rate of ${ }^{14} \mathrm{CO}_{2}$ evolution from $\left[6-{ }^{14} \mathrm{C}\right]$ fructose than from $\left[6-{ }^{14} \mathrm{C}\right]$ glucose and is also consistent with the FBP aldolase activity being high in phototrophically-grown cells. In addition, pyruvate kinase has half the activity in phototrophically growing bacteria compared with aerobically growing bacteria (Schedel, Klemme \& Schlegel, I975).

With the 6-PG dehydratase ${ }^{-}$strain of $R$. sphaeroides, fructose was degraded to a major extent via the EMP even under aerobic growth conditions, although some was apparently catabolized via the KDG-bypass of the EDP. Furthermore, the growth rate of this strain under aerobic growth conditions on fructose was lower than that of the strain containing 6-PG dehydratase activity. The growth rates for phototrophic growth on fructose, however, were the same in both strains, suggesting that one of the enzymes of the EMP was limiting for growth on fructose whenever the cultivation conditions were aerobic and the EDP was not functional.

This suggestion was confirmed by the discovery that the biosynthesis of FBP aldolase was repressed under aerobic conditions. It was therefore concluded that this enzyme was ratelimiting for the operation of the EMP under aerobic growth conditions, resulting either in a 


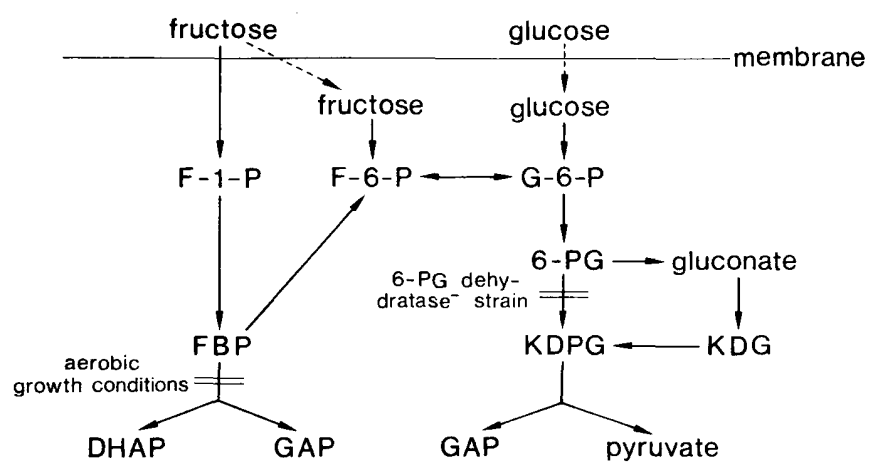

Fig. 5. Pathways of glucose and fructose catabolism in $R$. sphaeroides. The continuous lines indicate the enzyme reactions which are of significance during the degradation of glucose and fructose. The broken lines indicate reactions which are also of significance but have not been tested. Bars indicate a metabolic block. DHAP, Dihydroxyacetone phosphate; GAP, glyceraldehyde 3-phosphate.

slow growth rate on fructose or in an increased contribution of the EDP to fructose breakdown. The repression of FBP aldolase under aerobic growth conditions parallels the repression of ribulose-I,5-bisphosphate carboxylase in the same bacterium (Lascelles, 1960); both enzymes are essential for the operation of the Calvin cycle, which is not functional in $R$. sphaeroides during aerobic growth.

In contrast to fructose, glucose was always catabolized via the EDP. This was shown by radiorespirometric experiments with aerobically- and phototrophically-grown bacteria and by incorporation of specifically-labelled glucose into ether-soluble material. Growth on glucose was very poor in the 6-PG dehydratase- strain of $R$. sphaeroides, suggesting that glucose breakdown was limited by the activity of the KDG-bypass (Fig. 5).

The results of the radiorespirometric experiments are fully consistent with the enzyme data (Fig. 5). A constitutive glucokinase activity enabled the bacteria to phosphorylate intracellular glucose. Nothing is known about the glucose transport system in $R$. sphaeroides. The presence of a PEP-glucose phosphotransferase system, however, has been anticipated by the finding that $\alpha$-methyl glucoside transport is inhibited by vinylglycollic acid, which is known to inhibit PEP-phosphotransferase systems (Snyder et al., 1976). The constitutive presence of high phosphoglucose isomerase but low 6-phosphofructokinase activities apparently did not allow a significant contribution of the EMP to glucose catabolism. Glucose-6-phosphate dehydrogenase, 6-PG dehydratase and KDPG aldolase, however, were highly active in both glucose-grown and fructose-grown bacteria, allowing the breakdown of G-6-P via the EDP. Fructose-grown bacteria contained, in addition, a PEP-fructose phosphotransferase system (Saier et al., 197I) and I-phosphofructokinase activity, indicating that the initial steps in fructose catabolism involved a PEP-dependent phosphorylation of fructose followed by the conversion of the resulting F-I-P to FBP. Under phototrophic growth conditions the FBP was split by the action of FBP aldolase, but this was not possible under aerobic growth conditions when FBP aldolase was repressed. Under the latter conditions fructose was catabolized via the EDP, but the reaction sequence by which it was channelled into the EDP remains unexplained. There seem to be two possibilities. (I) In addition to the PEP-fructose phosphotransferase system, a system which transports unphosphorylated fructose might operate, as in Arthrobacter pyridinolis (Wolfson et al., 1974). Intracellular fructose could be catabolized via the EDP, as all the necessary enzyme activities - fructokinase, phosphoglucose isomerase, G-6-P dehydrogenase, 6-PG dehydratase and KDPG aldolase - were present in fructose-grown bacteria. (2) No phosphofructomutase activity converting F-I-P to F-6-P could be detected in extracts, whereas 
fructose 1,6-bisphosphatase activity forming F-6-P from FBP was low but easily detectable. (No attempt was made to find the optimal assay conditions for the fructose I,6-bisphosphatase reaction.) Thus a pathway leading from fructose via F-I-P, FBP, F-6-P and G-6-P into the EDP is also conceivable, as has been discussed by Conrad \& Schlegel (1977) and Sawyer et al. (1977a).

We thank Dr Karin Schmidt (Göttingen) for methodological advice during the spheroidene-labelling experiments and Dr P. Baumann (California) for sending us instructions for the alanine-labelling experiments. The help of Ing. grad. K. Fait and Mrs Adelheit Graser (Zentrales Isotopenlaboratorium der Universitat Göttingen), who performed the chromatogram scanning and autoradiography, is highly appreciated.

\section{REFERENCES}

AKaGI, J. M. \& JACkson, G. (1967). Degradation of glucose by proliferating cells of Desulfotomaculum nigrificans. Applied Microbiology 15, 1427-1430.

ANDREesen, J. R. \& GotTschalk, G. (1969). The occurrence of a modified Entner-Doudoroff pathway in Clostridium aceticum. Archiv für Mikrobiologie 69, 160-170.

Bender, R. \& Gottschalk, G. (1973). Purification and properties of D-gluconate dehydratase from Clostridium pasteurianum. European Journal of Biochemistry 40, 309-32I.

Blevins, W. T., Feary, T. W. \& PhibBs, P. V., $J_{R}$ (1975). 6-Phosphogluconate dehydratase deficiency in pleiotropic carbohydrate-negative mutant strains of Pseudomonas aeruginosa. Journal of Bacteriology 121, 942-949.

Blumenthal, H. J., Huettner, C. F. \& Montiel, F. A. (1974). Comparative aspects of glucose catabolism in Staphylococcus aureus and $S$. epidermidis. Annals of the New York Academy of Sciences 236, I05-I I4.

Brown, A. T. \& Wittenberger, C. L. (I97I). Mechanism for regulating the distribution of glucose carbon between the Embden-Meyerhof and hexose-monophosphate pathways in Streptococcus faecalis. Journal of Bacteriology 106, 456467.

Conrad, R. \& Schlegel, H. G. (I974). Different pathways for fructose and glucose utilization in Rhodopseudomonas capsulata and demonstration of I-phosphofructokinase in phototrophic bacteria. Biochimica et biophysica acta 358, $221-225$.

ConRad, R. \& Schlegel, H. G. (1977). Different degradation pathways for glucose and fructose in Rhodopseudomonas capsulata. Archives of Microbiology 112, 39-48.

Dawson, P. S. S. \& Westlake, D. W. S. (1975). Changes in patterns of respiration and glucose utilization in Candida utilis during the cell cycle: some variations with growth rate. Canadian Journal of Microbiology 21, IOI3-IOI9.

Eimhjellen, K. E. \& LiaAen-Jensen, S. (1964). The biosynthesis of carotenoids in Rhodopseudomonas gelatinosa. Biochimica et biophysica acta 82, 2 I-40.

Fraenkel, D. G. \& Levisohn, S. R. (1967). Glucose and gluconate metabolism in an Escherichia coli mutant lacking phosphoglucose isomerase. Journal of Bacteriology $93, \mathrm{I} 57 \mathrm{I}-\mathrm{I} 578$.
Gottschalk, G., Eberhardt, U. \& Schlegel, H. G. (1964). Verwertung von Fructose durch Hydrogenomonas HI6 (I). Archiv für Mikrobiologie 48, 95-108.

Hinks, N. T., Mills, S. C. \& Setchell, B. P. (I966). A simple method for the determination of the specific activity of carbon dioxide in blood. Analytical Biochemistry 17, 55I-553.

Julian, G. S. \& Bulla, L. A., JR (197I). Physiology of spore-forming bacteria associated with insects. IV. Glucose catabolism in Bacillus larvae. Journal of Bacteriology 108, 828-834.

KikUChI, G., SaIto, Y. \& MotokaWa, Y. (1965). On cytochrome oxidase as the terminal oxidase of dark respiration of non-sulfur purple bacteria. Biochimica et biophysica acta 94, I-14.

KLemme, J. H. \& SCHLEGel, H. G. (1969). Untersuchungen zum Cytochrom-Oxidase-System aus anaerob im Licht und aerob im Dunkeln gewachsenen Zellen von Rhodopseudomonas capsulata. Archiv für Mikrobiologie 68, 326-354.

LASCELlES, J. (1960). The formation of ribuloseI,5-diphosphate carboxylase by growing cultures of Athiorhodaceae. Journal of General Microbiology 23, 499-510.

Laughon, B. E. \& KRIEG, N. R. (1974). Sugar catabolism in Aquaspirillum gracile. Journal of Bacteriology 119, 691-697.

LIAAEN-JENSEN, S. (1962). The Constitution of some Bacterial Carotenoids and their Bearing on Biosynthetic Problems, Det KGL, Norske Videnskabers Selskabs Skrifter no. 8, Trondheim, Norway.

LYNCH, T. J. \& HenNeY, H. R., JR (1973). Carbohydrate metabolism during differentiation (sclerotization) of the myxomycete Physarum flavicomum. Archiv für Mikrobiologie 90, 189-198.

Morse, S. A., Stein, S. \& Hines, J. (I974). Glucose metabolism in Neisseria gonorrhoeae. Journal of Bacteriology 120, 702-714.

OHMANN, E., Rindt, K. P. \& Borriss, R. (1969). Glucose-6-phosphat-Dehydrogenase in autotrophen Mikroorganismen. I. Die Regulation der Synthese der Glucose-6-phosphat-Dehydrogenase in Euglena gracilis and Rhodopseudomonas spheroides in Abhängigkeit von den Kulturbedingungen. Zeitschrift für allgemeine Mikrobiologie 9, 557-564. 
Orlowski, M. \& Goldman, M. (1975). Inactivation of glucose 6-phosphate dehydrogenase during germination and outgrowth of Bacillus cereus $\mathbf{T}$ endospores. Biochemical Journal 148, 259-268.

Palumbo, S. A. \& Witlev, L. D. (1969). The influence of temperature on the pathways of glucose catabolism in Pseudomonas fluorescens. Canadian Journal of Microbiology r5, 995-100 I.

PATAKI, G. (1966). Dünnschichtchromatographie in der Aminosäure- und Peptid-Chemie, Berlin: Walter de Gruyter \& Co.

Phirbs, P. V. \& MCNAmee, C. (1976). Evidence against an oxidative hexose monophosphate pathway in the fluorescent group of Pseudomonas. Abstracts of the Annual Meeting of the American Society for Microbiology, p. 167. Washington: ASM.

SAier, M. H., JR, Feucht, B. U. \& Roseman, S. (I97I). Phosphoenolpyruvate-dependent fructose phosphorylation in photosynthetic bacteria. Journal of Biological Chemistry 246, 7819-782 I.

Sawyer, M. H., BaumanN, P., BaumanN, L., Berman, S. M., Cánovas, J. L. \& Berman, R. H. (1977a). Pathways of D-fructose catabolism in species of Pseudomonas. Archives of Microbiology II2, 49-55.

Sawyer, M. H., BaumanN, P. \& BaumanN, L. $(1977 b)$. Pathways of D-fructose and D-glucose catabolism in marine species of Alcaligenes, Pseudomonas marina and Alteromonas communis. Archives of Microbiology 112, 169-172.

Schedel, M., Klemme, J. H. \& Schlegel, H. G. (1975). Regulation of $\mathrm{C}_{3}$-enzymes in facultative phototrophic bacteria. The cold-labile pyruvate kinase of Rhodopseudomonas spheroides. Archives of Microbiology 103, 237-245.

Schmidt, K., Pfennig, N. \& Liaaen-Jensen, S. (1965). Carotenoids of Thiorhodaceae. IV. The carotenoid composition of 25 pure isolates. Archiv für Mikrobiologie 52, 132-146.
SNyder, M. A., Kaczorowski, G. J., BARnes, E. M., \& JR WALSH, C. (1976). Inactivation of the phosphenolpyruvate-dependent phosphotransferase system in various species of bacteria by vinylglycolic acid. Journal of Bacteriology 127, 671673 .

Szymona, M. \& Doudoroff, M. (1960). Carbohydrate metabolism in Rhodopseudomonas spheroides. Journal of General Microbiology 22, I 67-183.

TABita, R. \& Lundgren, D. G. (I97I). Heterotrophic metabolism of the chemolithotroph Thiobacillus ferrooxidans. Journal of Bacteriology I08, 334-342.

TAUSSKY, H. H. \& SHORR, E. (1953). A microcolorimetric method for the determination of inorganic phosphorus. Journal of Biological Chemistry 202, 675-685.

Thore, A., Keister, D. L. \& San Pietro, A. (ig69). Studies on the respiratory system of aerobically (dark) and anaerobically (light) grown Rhodospirillum rubrum. Archiv für Mikrobiologie 67, 378-396.

WANG, C. H. \& KRACKov, J. K. (1962). The catabolic fate of glucose in Bacillus subtilis. Journal of Biological Chemistry 237, 3614-3622.

WEISSBACH, A. \& HuRWITZ, J. (1959). The formation of 2-keto-3-deoxyheptonic acid in extracts of

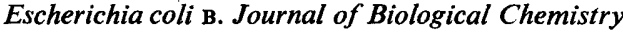
234, 705-709.

Willard, J. M., Schulman, M. \& Gibis, M. (1965). Aldolase in Anacystis nidulans and Rhodopseudomonas spheroides. Nature, London 206, 195.

Wolfson, E. B., Sobel, M. E., Blanco, R. \& KrulWICH, T. A. (1974). Pathways of D-fructose transport in Arthrobacter pyridinolis. Archives of Biochemistry and Biophysics r6o, 440-444.

WoOD, A. P. \& Kelly, D. P. (1976). Triple mechanism for glucose oxidation in Thiobacillus A2. Proceedings of the Society for General Microbiology 4, 23-24. 